\author{
(1)
}

\title{
STRATEGI MARKETING MIX DALAM MENGHADAPI PERSAINGAN PASAR : STUDI KASUS PADA PT. ZAMZAM SUMBULA THOYYIBA TANGERANG SELATAN
}

\author{
M Zein Ramadhan Rifa'I, Muhamad Zen \\ UIN Syarif Hidayatullah Jakarta \\ mramdanrifai17@gmail.com,zen@uinjkt.ac.id
}

\begin{tabular}{l}
\hline Article Info \\
\hline Article history: \\
Received 15 April 2021 \\
Accepted 15 Juni 2021 \\
Published 22 Juli 2021 \\
Page : 148 - 162 \\
\hline
\end{tabular}

Keyword:

Strategi, Marketing Mix, Persaingan, Pasar

\begin{abstract}
Currently, the number of PIHKs in Indonesia in 2021 is 348 and the number of PPIUs to date is 1313, the large number has opened up increasingly fierce market competition. As time goes by, the interest of the Indonesian Muslim community who wants to perform the Hajj and Umrah is increasing. The purpose of this study was to the formulation and then the implementation and evaluation of the marketing mix strategy carried out by PT. Zamzam Sumbula Thoyyiba in the face of market competition, which consists of seven marketing mix variables developed, namely product, price, promotion, place, people, process and physical evidence. The research method used in this study is a qualitative research method that produces descriptive data expressed in the form of sentences and descriptions using data collection techniques, namely interviews, observations, documentation and other supporting data. The results of this study, the authors conclude that PT. Zamzam Sumbula Thoyyiba has formulated, implemented and evaluated the 7P marketing mix strategy in accordance with the company's goals and does not consider other companies to be competitors or enemies but friends of an association that can be invited to cooperate.
\end{abstract}

Pada saat ini jumlah PIHK di Indonesia pada tahun 2021 sebanyak 348 dan jumlah PPIU sebanyak 1313, banyaknya jumlah tersebut maka telah membuka persaingan pasar semakin ketat. Seiring berjalannya waktu, besarnya minat masyarakat muslim Indonesia yang ingin melaksanakan ibadah haji maupun umrah semakin meningkat. Tujuan penelitian ini untuk mengetahui perumusan kemudian implementasi dan evaluasi strategi marketing mix yang dilakukan oleh PT. Zamzam Sumbula Thoyyiba dalam menghadapi persaingan pasar, yang terdiri dari tujuh variable bauran pemasaran yang dikembangkan yaitu produk, harga, promosi, tempat, orang, proses dan bukti fisik. Metode penelitian yang digunakan adalah dengan metode penelitian kualitatif yang menghasilkan data deskriptif yang diungkapkan dalam bentuk kalimat serta uraian-uraian dengan menggunakan teknik pengumpulan data yaitu wawancara, observasi, dokumentasi dan data penunjang lainnya. Hasil penelitian ini, penulis menyimpulkan bahwa PT. Zamzam Sumbula Thoyyiba telah melakukan formulasi, implementasi dan evaluasi strategi marketing mix 7P sesuai dengan tujuan perusahaan serta tidak menganggap perusahaan lain adalah pesaing tetapi kawan satu asosiasi yang dapat diajak kerjasama.

Copyright (C) 2021 Journal Of Islamic Management.

Editorial Office:

Program Studi Manajemen Dakwah, Fakultas Dakwah dan Komunikasi, UIN Sunan Ampel Surabaya.

Jl. Ahmad Yani 117 Surabaya, Jawa Timur, Indonesia.

Email:jim@uinsby.ac.id 


\section{Pendahuluan}

Ibadah haji merupakan rukun Islam yang ke lima, hukumnya wajib dilaksanakan sekali dalam seumur hidup bagi setiap orang Islam yang telah memenuhi syarat Istithoah baik dari segi biaya, fisik, mental serta jaminan keamanan selama melaksanakan ibadah haji. Dasar hukum melaksanakan ibadah haji dan umrah terdapat didalam kitab suci Al-Qur'an serta Hadits Nabi Saw.

Allah SWT telah berfirman di dalam Al-Qur'an Surat Al-Imran ayat 97:

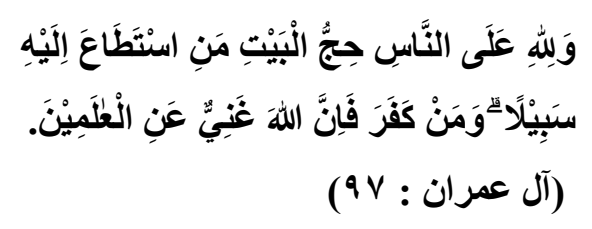

Artinya: "Mengerjakan haji adalah kewajiban manusia terhadap Allah, yaitu (bagi) orang yang sanggup mengadakan perjalanan ke Baitullah; Barang siapa mengingkari (kewajiban haji), maka sesungguhnya Allah Maha Kaya (tidak memerlukan sesuatu) dari semesta alam". (Q.S Ali- Imran : 97)

Rasulullah SAW bersabda didalam salahsatu hadits yang diriwayatkan dari Umar bin Khattab R.A:

\footnotetext{
${ }^{1}$ Ibnu Majah, Sunan Ibnu Majah, Juz 2 (t.t: Dar Ihya Al Kutub Al-Arobiyah, t.th), hal. 964
}

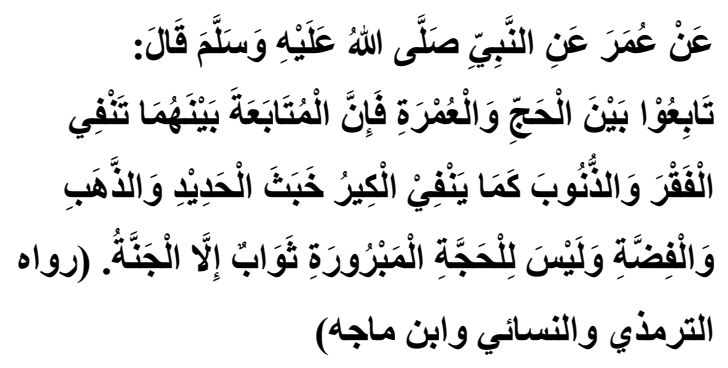

Artinya: "Dari Umar r.a. dari Nabi saw. beliau bersabda, "Dekatkanlah kalian antara haji dan umrah (baik haji diikuti dengan umrah atau umrah diikuti dengan haji), karena sesungguhnya mendekatkan di antara keduanya itu dapat menghilangkan kefaqiran dan dosa-dosa (yang kecil-kecil) sebagaimana kir (tempat yang digunakan untuk menyalakan api) dapat menghilangkan kotoran besi, emas, dan perak. Dan tidak ada pahala (yang pantas) bagi haji mabrur kecuali surga". (H.R. At-Tirmidzi, An-Nasa'i, dan Ibnu Majah No. 2887, Bab Fadhlul Haji Wal Umrah ). ${ }^{1}$

Melaksanakan ibadah haji adalah impian bagi setiap muslim, baik di negara kita Indonesia maupun negara muslim lainnya di dunia, karena terdapat banyak keutamaan serta hikmah yang terkandung didalam menunaikan ibadah haji dan umrah ke tanah suci Mekkah, serta dapat berziarah ke makam nabi di Madinah. ${ }^{2}$ Seiring berjalannya waktu dari tahun ke

\footnotetext{
2 Ahmad Kartono, Solusi Hukum Manasik Permasalahan Ibadah Haji, (Tanggerang Selatan: Pustaka Cendekiamuda, 2016), hal. 1
} 
tahun, jumlah jemaah haji dan umrah terus mengalami peningkatan. Banyak hal yang mempengaruhi tujuan jemaah haji dan umrah dalam melaksanakan ibadah haji, diantaranya untuk menyempurnakan rukun Islam, memenuhi panggilan Allah SWT, berziarah ke makam Rasulullah SAW dan meningkatkan strata sosial di masyarakat.

Besarnya animo muslim Indonesia untuk menunaikan ibadah haji dan umrah setiap tahunnya cukup tinggi, lebih dari 210 ribu jemaah haji setiap musimnya dan lebih dari seribu jemaah umrah setiap tahunnya, hingga saat ini lebih dari 3,5 juta calon jemaah yang sudah waiting list (daftar tunggu), menunggu antrian berangkat ke tanah suci. ${ }^{3}$ Kondisi tersebut telah membuka peluang dunia usaha, khususnya bagi Travel biro perjalanan, untuk turut serta dalam memberikan pelayanan kepada masyarakat muslim Indonesia. Keterlibatan usaha telah diatur dalam Undang-undang penyelenggaraan ibadah haji dan umrah (PIHU) Nomor 8 tahun 2019, pada Bab VI Tentang PIHK, pasal 57 sampai 58 dan Bab VII tentang PPIU, pasal 58 sampai 126. Bahwa lembaga swasta atau masyarakat diperbolehkan untuk turut serta dalam penyelenggaraan ibadah haji dan umrah,

${ }^{3}$ Ade Marpudin, Strategi Pemasaran Jasa Haji dan Umrah, (Tanggerang Selatan: Al Qolam, 2020), hal. 123 dengan catatan lembaga tersebut memiliki izin yang dikeluarkan oleh pemerintah (Kemenag RI)

Pada saat ini jumlah PIHK di Indonesia yang telah memiliki izin resmi dan aktif sebanyak 348 dan jumlah PPIU sampai saat ini sebanyak 1313, (berdasarkan data dari Simpu Kemenag tahun 2021). Dari banyaknya jumlah PIHK dan PPIU tersebut maka telah membuka persaingan pasar yang semakin ketat. Oleh karena itu setiap instansi penyelenggara haji khusus dan penyelenggara ibadah umrah (Travel Biro) harus menginisiasikan strategi pemasarannya masing-masing untuk mendapatkan jemaah yang sebanyak-banyaknya. Dalam hal pemasaran, salahsatunya perusahaan dapat menggunakan strategi bauran pemasaran (marketing mix), menurut Ade Marpudin marketing mix strategy atau strategi bauran pemasaran ialah kumpulan variabelvariabel yang telah digunakan perusahaan untuk mempengaruhi tanggapan konsumen. Variabel-variabel yang mempengaruhi atas pembelian tersebut sering disebut 7P yaitu product, price, place, promotion, participant, process, dan physical evidence. ${ }^{4}$

Dari fakta diatas maka setiap

\footnotetext{
${ }^{4}$ Ade Marpudin, Strategi Pemasaran Jasa Haji dan Umrah, hal. 127
} 
Travel Biro baik PIHK maupun PPIU dapat menerapkan strategi bauran pemasaran (marketing mix) untuk memenangkan persaingan pasar yang luar biasa ketat, sehingga dapat menarik jumlah jemaah sebanyak-banyaknya. Hal itu tidak dapat dilakukan apabila perusahaan tidak mempunyai cara atau strategi untuk mensiasati persaingan pasar dalam memasarkan pelayanan jasa pada perjalanan ibadah haji khusus maupun umrah. PT. Zamzam Sumbula Thoyyiba adalah salahsatu travel yang bergerak di bidang Biro perjalanan ibadah umrah dan haji khusus yang lahir dari banyaknya minat masyarakat yang ingin pergi ke tanah suci untuk melakukan ibadah haji maupun ibadah umrah, khususnya di negara Indonesia dengan populasi muslim terbesar di dunia. Yang mana PT. Zamzam Sumbula Thoyyiba telah lebih dari 20 tahun melayani kebutuhan jemaah beribadah ke Baitullah. Oleh karena itu PT. Zamzam Sumbula Thoyyiba telah lama bersaing dengan travel lain dengan memberikan pelayanan jasa terhadap jemaah. Melalui strategi bauran pemasaran (marketing mix) baik strategi harga, promosi, produk, tempat, sumber daya manusia, proses dan bukti fisik yang

\footnotetext{
${ }^{5}$ Fandy Tjiptono, Strategi Pemasaran, (Jogjakarta: C.V Andi Offset, 2008) Edisi 3 hal. 3
}

ditawarkan serta memberikan kelayakan fasilitas terhadap jemaah, yang menjadikan PT. Zamzam Sumbula Thoyyiba layak bersaing dengan perusahaan lain melalui strategi marketing mix yang dilakukan.

\section{Kajian Pustaka}

Strategi berasal dari bahasa Yunani strategis yaitu stratos dan ageia. Stratos berarti militer sedangkan ageia berarti memimpin yang artinya seni atau ilmu untuk menjadi jendral. Konsep ini relevan dengan situasi pada zaman dulu yang sering diwarnai perang, dimana jendral dibutuhkan untuk memimipin suatu angkatan perang agar dapat selalu memenangkan perang. ${ }^{5}$

Secara umum, pengertian strategi merupakan cara untuk mencapai tujuan jangka panjang. Menurut Ade Marpudin mengutip dari Dafit bahwa strategi adalah rencana tindakan yang memaparkan mengenai alokasi sumber daya dan aktifitas-aktifitas untuk menanggapi lingkungan dan membantu mencapai sasaran atau tujuan organisasi. ${ }^{6}$

Menurut Taufiqurokhman yang mengutip pendapat Fred R. David bahwa tahapan dalam manajemen strategi adalah formulating (perumusan), implementing

\footnotetext{
${ }^{6}$ Ade Marpudin, Strategi Pemasaran Jasa Haji dan Umrah, (Tanggerang Selatan: Al Qolam, 2020), hal. 2
} 
(pelaksanaan) dan evaluating (evaluasi) keputusan-keputusan yang memungkinkan organisasi mencapai tujuannya. ${ }^{7}$

\section{Perumusan strategi (formulating)}

Meliputi kegiatan untuk mengembangkan visi dan misi organisasi, mengidentifikasi peluang dan ancaman eksternal organisasi, menentukan kekuatan dan kelemahan internal organisasi, menetapkan tujuan jangka panjang organisasi, membuat sejumlah strategi alternatif untuk organisasi, serta memilih strategi tertentu untuk digunakan.

\section{Pelaksanaan strategi (implementing)}

Mencakup pengembangan budaya yang mendukung strategi, penciptaan struktur organisasi yang efektif, pengarahan kembali usaha-usaha pemasaran, penyiapan anggaran, pengembangan dan pemanfaatan sistem informasi, serta menghubungkan kompensasi untuk karyawan dengan kinerja organisasi

\section{Evaluasi strategi (evaluating)}

Tahap ini merupakan tahap akhir dari manajamen strategik, tiga kegiatan pokok dalam evaluasi strategi adalah mengkaji ulang faktor-faktor eksternal dan internal yang menjadi landasan perumusan strategi yang diterapkan sekarang ini. Kemudian mengukur kinerja, melakukan tindakan- tindakan korektif. Evaluasi strategi perlu dilakukan karena keberhasilan saat ini bukan merupakan jaminan untuk keberhasilan di hari esok.

Menurut Philip Kotler Pemasaran (marketing) adalah mengidentifikasi dan memenuhi kebutuhan manusia dan sosial dengan cara yang menguntungkan. Philip Kotler juga mengutip dari American Marketing Association (AMA) yang berpendapat bahwa Pemasaran adalah suatu fungsi organisai dan serangkaian proses untuk menciptakan, mengomunikasikan, dan memberikan nilai kepada pelanggan dan untuk mengelola hubungan pelanggan dengan cara yang menguntungkan organisasi dan pemangku kepentingannya. ${ }^{8}$

Allah SWT telah berfirman di dalam Al-Qur'an Surat An - Nisa ayat 29:

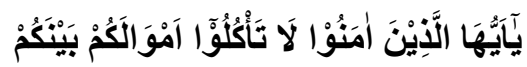

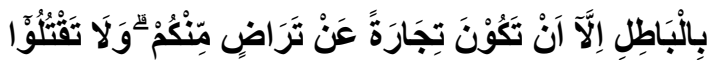

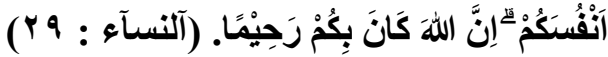

Artinya: "Wahai orang-orang yang beriman! Janganlah kamu saling memakan harta sesamamu dengan jalan yang batil (tidak benar), kecuali dalam perdagangan yang berlaku atas dasar suka sama suka di

\footnotetext{
${ }^{8}$ Philiph Kotler dan Kevin Lane Keller, Manajemen Pemasaran, Terj. Bob Sabran, (Jakarta: Erlangga, 2008), Edisi 13, hal. 5

7 Taufiqurokhman, Manajemen Strategik, (Jakarta: Fakultas Ilmu Sosial dan Ilmu Politik Universitas Prof. Dr. Moestopo Beragama, 2016), hal. 17-18
} 
antara kamu. Dan janganlah kamu membunuh dirimu. Sungguh, Allah Maha Penyayang kepadamu". (Q.S An - Nisa : 29)

Menurut Philip Kotler dan Hermawan Kartajaya bahwa untuk saaat ini pemasaran terbagi menjadi dua bagian yaitu pemasaran tradisional dan pemasaran digital, pemasaran tradisional memainkan peran utama dalam membangun kesadaran dan minat yang bertujuan untuk memepererat hubungan antara perusahaan dan pelanggan, sedangkan pemasaran digital untuk mendorong tindakan dan penganjuran karena pemasaran digital lebih akuntabel daripada pemasaran tradisional. ${ }^{9}$

Bauran pemasaran (marketing mix) adalah kumpulan dari variabel-variabel pemasaran yang dapat dikendalikan serta digunakan oleh suatu badan usaha untuk mencapai tujuan pemasaran dalam pasar sasaran. Jadi, bauran pemasaran (marketing mix) terdiri dari himpunan variabel yang dapat dikendalikan dan digunakan oleh perusahaan untuk mempengaruhi tanggapan para pembeli atau konsumen dalam pasar sasarannya. ${ }^{10}$

9 Philip Kotler, Hermawan Kartajaya, Iwan Setiawan, Marketing 4.0 Bergerak Dari Tradisional Ke Digital, Terj. Fairano Ilyas, (Jakarta: PT Gramedia Pustaka Utama, 2017), hal. 49

10 Ade Marpudin, Strategi Pemasaran Jasa Haji dan Umrah, hal. 166
Strategi bauran pemasaran ialah suatu yang dapat dilakukan oleh perusahaan untuk mempengaruhi permintaan akan produknya yang terdiri atas 4 kelompok yaitu product (produk), price (harga), promotion (promosi), dan place (tempat atau distribusi). ${ }^{11}$

Strategi bauran pemasaran adalah strategi dalam pemasaran untuk mencapai tujuan organisasi dan mendapatkan konsumen. Model bauran pemasaran menekankan pada berbagai faktor yang dikenal dengan sebutan 4P yaitu produk, harga, tempat, promosi (product, price, place dan promotion).

Seiring dengan pertumbuhan dan perkembangan zaman, bauran pemasaran jumlahnya meluas hingga tujuh yaitu, produk, harga, promosi, tempat, orang (personel, people), proses (process) dan bukti fisik (physical evidence). Bauran pemasaran merupakan sekumpulan alat pemasaran terkendali yang digunakan oleh perusahaan untuk menghasilkan respon yang diinginkan oleh pasar sasaran. ${ }^{12}$

Perusahaan harus melakukan strategi yang berhubungan dengan kegiatan pemasaran, menurut Sukotjo dan

11 Ade Marpudin, Strategi Pemasaran Jasa Haji dan Umrah, hal. 166

12 Ida Farida dan Achmad Tarmizi, "Analisis Pengaruh Bauran Pemasaran 7P Terhadap Kepuasan Pelanggan Pengguna Gojek Online". Jurnal Riset Manajemen dan Bisnis. Vol.1, No.1, Juni 2016, hal. 34 
Sumanto mengutip arti dari marketing mix strategy yang didefinisikan oleh Kotler dan Amstrong yang menyatakan bahwa "kumpulan dari variabel pemasaran yang dapat dikendalikan dan dikelola oleh perusahaan dengan tujuan untuk mendapatkan respon dari pasar sasaran". ${ }^{13}$

Dari definisi diatas dapat diartikan bahwa bauran pemasaran ialah seperangkat variabel terkendali yang disatukan untuk menghasilkan tanggapan dari pasar sasaran. Dan untuk usaha jasa terdapat 7 unsur marketing mix (Marketing Mix-7p) yaitu: Product, Price, Promotion, Place, Participant, Process, dan Physical Evidence. ${ }^{14}$

\section{Product (produk)}

Secara konseptual produk adalah pemahaman subyektif produsen atas sesuatu yang bisa ditawarkan sebagai usaha untuk mencapai tujuan organisasi melalui pemenuhan kebutuhan dan keinginan konsumen, sesuai kompetensi dan kapasitas organisasi serta daya beli pasar. Selain itu, produk dapat pula didefinisikan sebagai persepsi konsumen

${ }^{13}$ Hendri Sukotjo dan Sumanto Radix A, "Analisa Marketing Mix-7P (Produk, Price, Promotion, Place, Partisipant, Process, dan Physical Evidence) terhadap Keputusan Pembelian Produk Klinik Kecantikan Teta di Surabaya". Jurnal Mitra Ekonomi dan Manajemen Bisnis. Vol.1 No. 2, Oktober 2010, hal. 218 yang dijabarkan oleh produsen melalui hasil produksi atau operasinya. ${ }^{15}$

\section{Price (harga)}

Menurut Kotler pada dasarnya harga adalah salah satu elemen bauran pemasaran (markeing mix) yang dapat menghasilkan pendapatan, dimana elemen yang lain mendapatkan biaya. ${ }^{16}$ Harga (price) merupakan nilai angka yang dapat digunakan oleh suatu perusahaan dalam menetapkan biaya dari setiap produk yang telah di buat sesuai dengan kualitas dan kuantitas produk itu sendiri, baik berupa mata uang rupiah dan mata uang lainnya dari setiap negara.

\section{Promotion (promosi)}

Promosi adalah kegiatan komunikasi pemasaran yang mencakup berbagai teknik yang digunakan untuk berkomunikasi dengan para konsumen dan calon potensial konsumen. Promosi merupakan aspek penting dalam pemasaran yaitu memberikan informasi kepada calon konsumen atau kepada masyarakat luas, promosi juga salah satu ujung tombak dalam pemasaran. Dengan adanya promosi perusahaan dapat

\footnotetext{
${ }^{14}$ Ibid, hal. 219

15 Fandy Tjiptono, Strategi Pemasaran, hal. 231232.

16 Philiph Kotler dan Kevin Lane Keller, Manajemen Pemasaran, Terj. Bob Sabran, hal. 67
} 
memeperoleh kesempatan untuk berkomunikasi dengan konsumen. ${ }^{17}$

\section{Place (tempat atau distribusi)}

Distribusi menurut Ade Marpudin yang mengutip dari Soekartawi ialah aktivitas menyalurkan atau mengirimkan barang dan jasa supaya sampai konsumen akhir yakni kegiatan memindahkan produk dari sumber ke konsumen akhir dengan saluran distribusi pada waktu yang tepat. ${ }^{18}$

\section{People (orang)}

People atau orang adalah karyawan yang mampu menyediakan produk kemudia layanan jasa maupun penjualan, atau orang-orang yang terlibat secara langsung maupun tidak langsung dalam proses tersebut. People merupakan unsur internal dari pemasaran yang berupaya untuk melayani konsumen. People atau partisipan ini dapat dinilai dari service people (orang-orang yang terlibat langsung dalam memberikan pelayanan terhadap pelanggan. ${ }^{19}$

\section{Process (proses)}

17 Ade Marpudin, Strategi Pemasaran Jasa Haji dan Umrah, hal. 172

18 Ade Marpudin, Strategi Pemasaran Jasa Haji dan Umrah, hal. 72

19 Giri Dwinanda dan Yuswari Nur, "Bauran Pemasaran 7P Dalam Mempengaruhi Keputusan Pembelian Konsumen Pada Industri Retail Giant Express Makassar", hal. 123

${ }^{20}$ Hendri Sukotjo dan Sumanto Radix A, "Analisa Marketing Mix-7P (Produk, Price, Promotion,
Proses adalah suatu kegiatan yang menunjukkan bagaimana pelayanan yang diberikan oleh perusahaan kepada konsumen. Seperti contoh klinik dokter melalui front liner yang menawarkan berbagai macam pelayanan untuk tujuan menarik pelanggan. Yaitu fasilitas jasa konsultasi dokter secara gratis, resep obat, pengiriman produk, kartu anggota dan fasilitas lainnya yang berpengaruh terhadap citra perusahaan. ${ }^{20}$

\section{Physical Evidence (bukti fisik)}

Menurut Supriyanto dan Taali yang mengutip dari Zeithaml \& Bitner bahwa bukti fisik merupakan pelayanan jasa yang dilakukan melalui interaksi dengan konsumen dan setiap komoditas yang memberikan fasilitas serta performa dan komunikasi dalam pelayanan jasa itu sendiri. ${ }^{21}$

Persaingan adalah semua penawaran dan produk substitusi yang ditawarkan oleh pesaing, baik yang aktual maupun yang potensial, dengan kemungkinan akan menjadi bahan pertimbangan oleh pembeli. ${ }^{22}$ Strategi

Place, Partisipant, Process, dan Physical Evidence) terhadap Keputusan Pembelian Produk Klinik Kecantikan Teta di Surabaya", hal. 220

${ }^{21}$ Muhammad Supriyanto dan Muhammad Taali, "Pengaruh Bauran Pemasaran (Marketing Mix) Terhadap Pengambilan Keputusan Menginap di The Sun Hotel Madiun", hal. 15

22 Philiph Kotler dan Kevin Lane Keller, Manajemen Pemasaran, Terj. Bob Sabran, hal. 15 
bersaing adalah pencarian akan posisi bersaing yang menguntungkan di dalam suatu industri, area fundamental tempat persaingan terjadi. Strategi bersaing bertujuan untuk memenangkan posisi yang menguntungkan dan dapat dipertahankan terhadap kekuatan-kekuatan yang menentukan persaingan industri. ${ }^{23}$

Pasar dapat didefinisikan sebagai tempat dimana pembeli bertemu dengan penjual, barang-barang maupun jasa ditawarkan untuk dijual dan kemudian terjadi pemindahan hak milik. Pasar juga dapat diartikan sebagai permintaan yang diajukan oleh sekelompok pembeli yang potensial untuk sebuah produk atau jasa. ${ }^{24}$

Adapun tahapan-tahapan yang harus dijalani dan dimiliki oleh perusahaan untuk mematangkan sistem pemasaran terbagi menajdi tiga yaitu segmentasi pasar (segmentation), target pasar (targeting) dan posisi pasar (positioning).

\section{Metode Penelitian}

Metode yang digunakan dalam penelitian ini adalah dengan metode penelitian kualitatif yang menghasilkan data kualitatif deskriptif yang diungkapkan dalam bentuk kalimat serta uraian-uraian, bahkan dapat berupa cerita pendek pada beberapa data tertentu, serta dapat

23 Ade Marpudin, Strategi Pemasaran Jasa Haji dan Umrah, hal. 107

${ }^{24}$ William J. Stanton, Prinsip Pemasaran, Terj. Y. Lamarto, hal. 92 menunjukan perbedaan dalam bentuk jenjang atau tingkatan walaupun tidak jelas batas-batasnya. ${ }^{25}$ Serta dideskripsikan secara ilmiah dari data temuan penelitian.

Penelitian ini dilakukan dengan cara mengumpulkan data penelitian melalui wawancara (interview), yaitu proses tanya jawab dalam penelitian secara langsung kepada pimpinan perusahaan PT. Zamzam Sumbula Thoyyiba dan staff perusahaan baik secara lisan maupun tulisan. Dimana dua orang atau lebih bertatap muka mendengarkan secara langsung informasi-informasi atau keterangan. Kemudian dengan melakukan observasi melalui pengamatan langsung ke lapangan, dokumentasi, dan data-data yang dibutuhkan dalam penelitian yaitu mencari data berupa buku, catatan, arsip, dan sebagainya, yang berkaitan dengan lembaga.

\section{Hasil dan Pembahasan}

\section{Product (produk)}

Strategi dalam menetapkan produk PT. Zamzam Sumbula Thoyyiba fokus pada 3 (tiga) yaitu haji khusus, umrah dan muslim tour, "Jadi kita kan bergerak di bidang travel haji umrah, jadi fokus jasanya sebagai jasa penyelenggaraan

${ }^{25}$ M. Burhan Bungin, Metodologi Penelitian Sosial \& Ekonomi, (Jakarta: Kencana Prenada Media Group, 2013), Cet ke-1 hal. 124 
ibadah haji, haji nya juga haji khusus dan umrah, selama hampir 20 tahun dari tahun 2000 kita fokus di tiga bidang produk, yaitu: haji khusus, umrah dan muslim tour". 26
a. Haji khusus
b. Umrah
c. Muslim Tour

\section{Price (harga)}

Strategi dalam menetapkan harga PT. Zamzam Sumbula Thoyyiba tidak jauh dari harga yang telah ditetapkan oleh Kemenag, minimal harga umrah dari Kemenag itu Rp.20.000.000 dan untuk haji khusus itu minimal USD 9000, jadi untuk harga produk di PT. Zamzam Sumbula Thoyyiba ialah:

- Umrah: Rp.26.000.000Rp.36.000.000

- Haji Khusus: USD16.500USD20.000

- Muslim Tour: Rp.18.000.00030.000 .000

Akan tetapi PT. Zamzam Sumbula Thoyyiba tidak terlalu spesifik mengenai harga, bermain murah atau bermain mahal, tidak, karena sudah ada standarisasi minimal harga yang ditetapkan oleh Kemenag, tergantung bagaimana cara

\footnotetext{
${ }^{26}$ Hasil Wawancara dengan Mohamad Ali Ridho
} selaku Divisi Haji \& Umrah PT. Zamzam Sumbula perusahaan dalam mengemas produknya itu sendiri.

\section{Promotion (promosi)}

Startegi PT. Zamzam Sumbula Thoyyiba dalam mempromosikan produknya itu dibagi menjadi 2 (dua) bagian yaitu Online dan Offline:

1. Online

- Website

- Sosial Media

- Identitas Brand

2. Offline

- Melalui media cetak (brosur, flyer, Spanduk)

- Menjalin kerjasama dengan tokoh-tokoh yang memiliki jemaah

- Agent (pengumpul jemaah)

- Perwakilan

Jadi PT. Zamzam Sumbula Thoyyiba dalam melakukan promosi melalui media digital (Online) seperti website dan sosial media untuk menjangkau masyarakat yang sifatnya umum dan cakupannya ke seluruh Indonesia.

\section{Place (tempat)}

PT. Zamzam Sumbula Thoyyiba dalam menetapkan strategi tempat (place)

Thoyyiba, Jakarta, Selasa 16 Maret 2021 Pukul 13.05 WIB. 
lebih mengarah pada perluasan jaringan di luar, tidak terlalu mengutamakan internal kantor karena lebih efektif itu terjun langsung ke lapangan, bertemu dengan para tokoh para Kiyai, para Ustadz, para pimpinan pondok pesantren, karena mereka sudah memiliki jemaah, untuk soal kantor sebetulnya tidak terlalu berpengaruh terhadap pendapatan jemaah nya itu sendiri.

\section{People (orang)}

PT. Zamzam Sumbula Thoyyiba melakukan strategi dalam mengembangkan sumber daya manusia (SDM) di internal perusahaan itu dengan pembagian kerja (job specification), seleksi karyawan (recruitment), pelatihan karyawan dan motivasi kerja, yaitu:

\section{Pembagian kerja job specification)}

Untuk pembagian kerja PT. Zamzam Sumbula Thoyyiba memiliki berbagai Divisi diantaranya adalah: Direktur Utama, Keuangan, Tour Manager, Divisi Haji \& Umrah, Business Development, Administrasi, IT \& Sistem, Operasional Haji, Operasional Umrah dan Pembimbing Ibadah, yang bekerja sesuai bidangnya masing-masing, secara garis besar terdapat marketing yang menjaring eksternal dan bagian internal yang mengurus data administratif.

2. Seleksi karyawan (recruitment)

Tim PT. Zamzam Sumbula Thoyyiba terdiri dari para ustadz dan para professional yang bersertifikat dan telah terbukti berkualitas, secara pengetahuan maupun pengalaman dalam membimbing, mendampingi, serta melayani kebutuhan para jemaah.

3. Pelatihan karyawan

Untuk pelatihan karyawan itu diantaranya mengikuti training keluar, seperti pelatihan Tour Leader, Tour Guide, pelatihan eksternal yang direkomendasikan oleh asosiasi, pelatihan tentang administratif, mengikutsertakan pegawai-pegawai perusahaan yang memang dalam keseharian mengerjakan tugasnya.

4. Motivasi kerja

Dalam mengupayakan karyawan agar memiliki motivasi kerja yang tinggi, perusahaan memberikan bonus bagi karyawan yang mampu mencapai target yang telah ditentukan oleh perusahaan, kemudian dari internal melakukan 
sharing pengetahuan dari hasil pelatihan kepada karyawan lain untuk menambah motivasi kerja.

\section{Process (proses)}

PT. Zamzam Sumbula Thoyyiba melakukan proses dalam kegiatan perusahaan itu terdiri dari beberapa indikator proses yang diperlukan diantaranya adalah prosedur, kebijakan, mekanisasi, arah aktifitas, dan pelayanan perusahaan.

1. Prosedur dan kebijakan Perusahaan

\section{PT. Zamzam Sumabula}

Thoyyiba memiliki standar-standar kerja yang harus dipenuhi sebagai syarat diberikan izin, terkait SOP, Tata tertib, Sanksi, pelatihan untuk mendapatkan izin biro perjalanan wisata, karena setiap tahun di reakreditasi, di tinjau ulang oleh lembaga sertifikasi, di bawah KAN (Komite Akreditasi Nasional).

2. Mekanisasi dan arah aktifitas

PT. Zamzam Sumbula Thoyyiba memiliki IATA (Internasional Air Transportation), jadi perusahaan mempunyai izin untuk menjual tiket secara langsung, menjadi provider tiket resmi, dan berhak untuk menjual visa umrah, dan arah aktifitas perusahaan ialah menyelenggarakan perjalanan ibadah umrah dan ibadah haji khusus karena memiliki izin resmi PPIU dan PIHK untuk memfasilitasi jemaah yang ingin melaksanakan ibadah ke Baitullah.

3. Pelayanan Perusahaan

Secara pelayanan, kalau untuk pelayanan umrah PT. Zamzam Sumbula Thoyyiba itu gradenya B, tapi kalau untuk perjalanan ibadah haji khusus PT. Zamzam Sumbula Thoyyiba grade nya A, akan tetapi dari semua program baik umrah maupun haji khusus perusahaan akan memberikan fasilitas dan pelayanan yang terbaik kepada pelanggan.

\section{Physical Evidence (bukti fisik)}

PT. Zamzam Sumbula Thoyyiba memiliki lingkungan fisik berupa kantor operasional yang bertempat di Jalan Panglima Polim V No. 4, Melawai, Kebayoran Baru, Jakarta Selatan, Provinsi DKI Jakarta, sehingga memudahkan konsumen untuk melihat langsung kegiatan perusahaan baik berupa pelayanan, produk-produk dan harga yang 
ditawarkan hingga aktifitas kerja yang berlangsung didalam kantor.

\section{Kesimpulan}

Berdasarkan dari hasil penelitian, analisa data dan temuan penelitian yang telah penulis lakukan, secara garis besar kesimpulan yang dapat penulis paparkan diantaranya adalah:

1. Formulasi strategi bauran pemasaran (marketing mix) yang dilakukan oleh PT. Zamzam Sumbula Thoyyiba dalam menghadapi persaingan pasar yaitu menetapkan strategi produk sesuai dengan segmentasi pasar dan sisi bisnis perusahaan sebagai biro perjalanan wisata, kemudian strategi harga sesuai dengan acuan harga dari Kemenag, strategi promosi, sumber daya manusia dan bukti fisik dengan memperluas jaringan diluar, serta mengembangkan sumber daya manusia di internal perusahaan dan fokus untuk memberikan pelayanan yang terbaik kepada jemaah.

2. Implementasi strategi bauran pemasaran (marketing mix) yang dilakukan oleh PT. Zamzam Sumbula Thoyyiba dalam menghadapi persaingan pasar, produk hanya fokus pada tiga produk yaitu haji khusus, umrah dan muslim tour, kemudian strategi harga sesuai dengan paket yang ditawarkan dan fasilitas yang diberikan, serta lebih menekankan pada perluasan jaringan diluar dan adanya program berkesinambungan bagi alumni jemaah.

3. Evaluasi strategi bauran pemasaran (marketing mix) yang dilakukan oleh PT. Zamzam Sumbula Thoyyiba dalam menghadapi persaingan pasar yakni melakukan perbaikan dari setiap strategi yang dilakukan oleh perusahaan, dan juga tidak menganggap travel lain adalah musuh atau lawan tetapi sebgai kawan yang dapat diajak kerjasama, salahsatunya dengan melakukan konsorsium.

\section{Saran}

Setelah melakukan penelitian, pengamatan dan juga berdasarkan dari data temuan peneltitian pada PT. Zamzam Sumbula Thoyyiba, penulis mencoba untuk memeberikan saran yang kiranya dapat memberikan manfaat, diantaranya adalah:

1. Mencoba untuk membuka cabang perusahaan di berbagai kota dan juga lebih memperbanyak lagi perwakilan-perwakilan serta agent 
marketing di setiap daerah untuk menunjang dalam hal pendapatan jemaah.

2. Tetap konsisten dalam melakukan program pembinaan berkesinambungan yang bertujuan untuk tetap menjaga kemabruran jemaah haji maupun umrah dari sebelum keberangkatan dan setelah kepulangan.

3. Jangan sampai down karena pandemi Covid-19 yang membuat kegiatan perusahan tidak berjalan dengan baik, tetap bertahan dan melakukan strategi dalam menghadapi Pandemi ini.

\section{Daftar Pustaka}

Abdullah, Thamrin dan Tantri, Francis. 2019. Manajemen Pemasaran, Depok: Rajawali Pers.

Assauri, Sofjan. 2010. Manajemen Pemasaran, Jakarta: Raja Grafindo Persada.

Bungin, Burhan M. 2013. Metodologi Penelitian Sosial \& Ekonomi. Jakarta: Kencana Prenada Media Group.

J. Stanton, William. 2018. Prinsip Pemasaran, Terjemahan oleh Yohanes Lamarto. Jakarta: Erlangga.
Kartono, Ahmad. 2016. Solusi Hukum Manasik Permasalahan Ibadah Haji. Tanggerang Selatan: Pustaka Cendekiamuda.

Kotler, Philiph dan Keller, Kevin Lane. 2008. Manajemen Pemasaran, Terjemahan oleh Bob Sabran. Jakarta: Erlangga. . Kartajaya, Hermawan. Setiawan, Iwan. 2017. Marketing 4.0 Bergerak Dari Tradisional Ke Digital, Terjemahan oleh Fairano Ilyas. Jakarta: PT Gramedia Pustaka Utama.

Marpudin, Ade. 2020. Strategi Pemasaran Jasa Haji dan Umrah. Tanggerang selatan: Al Qolam. 2020. Event Organizing. Tanggerang selatan: Al Qolam. Narbuko, Chalid. dan Achmadi, Abu. 1997. Metode Penelitian. Jakarta: PT. Bumi Aksara.

Taufiqurokhman. 2016. Manajemen Strategik. Jakarta: Fakultas Ilmu Sosial dan Ilmu Politik Universitas Prof. Dr. Moestopo Beragama.

Tim Zamzam. 2020. Company Profile. Jakarta: PT. Zamzam Sumbula Thoyiba.

Tjiptono, Fandy. 2017. Strategi Pemasaran, Jogjakarta: C.V Andi Offset. 
Atmadja, Ferry Setyadi dan Sugiharto. 2019. "Strategi Pelayanan Prima Dalam Menumbuhkan Kepercayaan Jamaah Umrah Pada PT. Wisata Titian Nusantara Pelangi". Jurnal Manajemen Dakwah. $\quad 7(1)$ : hal. 23 http://journal.uinjkt.ac.id/index.ph p/jmd/article/view/19972/8461

Dwinanda, Giri dan Nur, Yuswani. 2020.

"Bauran Pemasaran 7P Dalam Mempengaruhi Keputusan Pembelian Konsumen Pada Industri

Retail Giant Express Makassar". Jurnal Mirai Management. 6(1): hal. 122-123

Farida, Ida dan Tarmizi, Ahmad. 2016.

"Analisis Pengaruh Bauran

Pemasaran 7P Terhadap Kepuasan

Pelanggan Pengguna Gojek

Online". Jurnal Riset Manajemen dan Bisnis. 1(1): hal. 34

Sukotjo, Hendri dan Radix A, Sumanto. 2010. "Analisa Marketing Mix-7P (Produk, Price, Promotion, Place, Partisipant, Process, dan Physical Evidence) terhadap Keputusan Pembelian Produk Klinik Kecantikan Teta di Surabaya". Jurnal Mitra Ekonomi dan Manajemen Bisnis. 1(2): hal. 218220
Supriyanto, Muhammad dan Taali, Muhammad. 2018. "Pengaruh Bauran Pemasaran (Marketing Mix) Terhadap Pengambilan Keputusan Menginap di The Sun Hotel Madiun". Epicheirisi. 2(1): hal. 14-15

Taufiq. 2018. "Memakan Harta Secara Bathil (Perspektif Surat An-Nisa:29 dan At-Taubah: 34)". Jurnal Ilmiah Syari 'ah. 17(2): hal. 249-250

Zen, Muhammad. "Strategi Pemasaran Syariah Pada Wirausaha Rumah Makan Wong Solo Dalam Meningkatkan Kepuasan Konsumen". Tesis, Sekolah Pascasarjana. UIN Jakarta. Jakarta. 2007.

\section{$\underline{\text { https://zamzamsumbula.com/ }}$}

